\title{
Jordanian Universities and Their Role in the Trend towards the Development of Technical Competence for Accounting Learning Outcomes in Line with IES \#2
}

\author{
Dr. Yaser S. AL Frijat ${ }^{1} \&$ Dr. Mohammad K. Shbeilat ${ }^{1}$ \\ ${ }^{1}$ Accounting Department / Business Faculty /Tafila Technical University, P. O. Box 179, Tafila 66110, Jordan \\ Correspondence: Dr. Yaser S. AL Frijat, Accounting Department / Business Faculty /Tafila Technical University, P. \\ O. Box 179, Tafila 66110, Jordan
}

Received: February 13, 2016

Accepted: March 7, 2016

Online Published: March 9, 2016

doi:10.5430/afr.v5n2p20

URL: http://dx.doi.org/10.5430/afr.v5n2p20

\begin{abstract}
The aim of the study is to identify the role of Jordanian universities in the trend towards the development of technical competence for accounting learning outcomes in line with the second international standard of accounting education (IES 2). In order to achieve the goals of this study, an analytical method was applied to the content of the plans and curricula of a random sample of 10 Jordanian universities, followed by conducting 8 interviews with academic staff and students in accounting. The study revealed a number of notable findings, chief of which is that Jordanian universities do not apply IES 2, whereby a high proportion of technical competence of educational curricula taught in accounting departments, do not comply with the content requirements stipulated in the IES 2. The study also revealed that the majority of educational courses taught in university accounting departments do not incorporate sufficient topics to provide the required knowledge, and some study plans of universities within the study sample have not been consistently and continuously updated and developed. Based on these findings, the study proposes a number of recommendations, chief of which is requiring Jordanian universities to work towards the standardization of accounting education plans across Jordanian universities as a prerequisite to mitigate the disparity in the results of university competency test among Jordanian universities. In pursuit of this recommendation, this study presents a suggested model for accounting study plan that complies with both IES 2 and the requirements of The Higher Education Accreditation Commission.
\end{abstract}

Keywords: International Accounting Education Standards (IAES), IES\#2, Technical competence, Accounting study plan \& curricula, Jordanian Universities

\section{Introduction}

The International Accounting Education Standards Board (IAESB) is focused on the development and modernization of accounting education, especially in light of the adoption of International Financial Reporting Standards (IFRS), in order to monitor and control educational inputs to produce outputs that are relevant to addressing the required goals of accounting education. Such education output should address the challenges that companies face in controlling accounts and preparing them more fairly and transparently in order to provide users with financial statements that are reliable and consistent, so that financial statements can be relied upon as the basis upon which companies can make many decisions regarding their activities and operations. For this reason, international standards of accounting education represent the primary foundations which should be considered in the development of accounting education curricula and the development of the knowledge and skills of accounting graduates, as well as keeping up with all developments related to education standards (Al-Jalili, Dhanoon, 2010).

Traditional accounting education has resulted in the failure of many universities in producing accounting graduates with the required accounting and financial knowledge, organization, financing, business and economics knowledge, as well as information technology knowledge. In 2010 and 2011, the biggest accounting and auditing firms provided funding to a number of universities in the US in order to develop and modernize accounting curricula to incorporate topics related to the IFRS (Weiss, 2011).

It is virtually certain that Jordanian universities and educational institutions will have the biggest role to play in any effort to apply these standards in Jordan, through producing professional accountants armed with the modern knowledge and skills to meet the needs of the market. 


\section{Importance of the Study}

The importance of the study arises from the need to understand the role of Jordanian universities as well as their effectiveness in developing and modernizing accounting education and programs in terms of professional knowledge related to accounting and financial sciences, as well as business, economics, finance and information technology, as stipulated in the second international standard of education, in order to produce qualified accounting talent capable of playing prominent role in the accounting job market, particularly given Jordan's adoption of the IFRS. This study also aims to improve the quality of the outcomes of the Jordanian universities competency test (Note 1) as there have been many debates and criticisms directed to the results of test. The main criticism attributed to the variation of the of the study plans among Jordanian universities, as a consequence, different inputs result in different outcomes. This study aims at reducing disparities among Jordanian universities results by proposing a unified accounting study plan to be adopted in the Jordanian universities.

\section{Research Statement and Questions}

A review of current literature has revealed shortcomings in universities' compliance with the second international standard of accounting education, particularly Jordanian universities, thus, this study aims at investigating the role of accounting departments in the Jordanian universities in the development of technical competence for accounting learning outcomes in conformity with (IES 2) for both The International Accounting Education Standards before adjustment (the issuance of 2005) and the subsequent issuances till 2015 (IES 2, 2014, para.10; IES 2, 2015, para.5).

The current study's primary research problem is as follows:

Primary question for study: What is the role of Jordanian universities in the trend towards the development of technical competence for accounting learning outcomes complying with the second international standard for accounting education?

Based on this primary research problem, the following secondary research questions are addressed:

Question One: What is the role of Jordanian universities in the trend towards the development of technical competence for accounting learning outcomes in the curricula for accounting and financial professional knowledge, in terms of compliance with the IES 2?

Question Two: What is the role of Jordanian universities in the trend towards the development of technical competence for accounting learning outcomes in the curricula for organization, finance, business and economic professional knowledge, in terms of compliance with the IES 2 ?

Question Three: What is the role of Jordanian universities in the trend towards the development of technical competence for accounting learning outcomes in the curricula for information technology professional knowledge, in terms of compliance with the IES 2?

\section{Research \& Data Collection Method}

The study employed mix method approach to investigate the role of Jordanian universities in the development of technical competence that complies with the IES 2, the following approaches were used:

1. Secondary Sources: The study referenced the most important modern studies, as well as previous Arab and international studies and articles, and information published in books, periodicals, magazines and conference proceedings of relevance to this study's subject area, in addition to internet sources.

2. Primary Sources:

(A) The study applied content analysis method to the study plans for accounting departments in Jordanian universities. These study plans were obtained by the universities' websites. The study population consisted of the 23 public and private Jordanian universities that offer accounting programs and satisfying the public and private accreditation standards. Ten universities were randomly selected to represent the study sample, the study sample consisted 6 public and 4 private universities. For the purpose of this study, the term study plan means: List of all courses and learning competence, whether compulsory or elective, that students need to successfully complete them in order to get their university certificate.

A) The researchers conducted 8 in-depth interviews with a sample of academic staff and graduate students in accounting selected from the sample universities. The main purpose of the interviews is to get deeper understanding about the reality of accounting education in Jordanian universities, to identify potential weaknesses, and searching ways to improve accounting programs. 


\section{Literature Review}

Many Arab and international studies have addressed the issue of international standards for accounting education and highlighted the importance of developing accounting curricula and building the professional knowledge of accounting graduates. Typical theoretical-based teaching does not meet the needs of modern markets, according to Gammie \& Joyce (2009), they highlighted the importance of evaluating accounting education using competence-based approaches based on the experience of The Institute of Chartered Accountants of Scotland. Abbasi, (2013) proposed a globally perspective of a competency model of accounting education based on the pronouncements of the AICPA and the IAESB. Albrecht \& Sack (2000) suggested a risky future for accounting education in the US given the variables in the work environment and their impact on accounting education programs; they have also argued that recommendations should be presented to improve the environment of accounting education.

Attia, and Al-Zahrani (2008) study discussed a suggested model for evaluating the academic quality of accounting education programs in Saudi universities. Among the study's most important findings was that the quality of teaching and learning was of medium quality, as was the effectiveness of the lesson plans in terms of keeping up with changes in technology.

A recent quantitative study conducted by Mohammad (2016) in Sudan to investigate the compliance of Sudanese universities with education strategy of the (IFAC) and the requirements of contemporary business environment. Questionnaires were distributed to a sample of 40 academic staff and 80 employers. The study revealed that accounting education system provided by Sudanese universities is incompatible with education strategy for vocational rehabilitation issued by the IFAC, to minimize that mismatch, the study recommended restructuring the curricula and study plans of Sudanese universities.

Alnawaisa \& Alsbou, (2009) study focused attention on accounting education curricula in Jordan and their impact on building and developing professional accounting knowledge and practices. The study sample consisted of the accounting students who were expected to graduate from the Applied Sciences University in 2008/2009. The study found that the courses, the teaching staff and faculty as well as field training each had a very significant impact on building and developing the knowledge and technical skills of the students.

A study by Chen et al. (2010) sought to identify the most notable technological skills acquired by graduates of accounting programs. Among the most important findings of the study was that students had insufficient knowledge in technological skills, due to deficiencies in information technology curricula.

In 2010, Al-Jalili, \& Dhanoon studied how international standards for accounting education could be used to develop accounting curricula for use in bachelor programs at Iraqi universities, in order to address deficiencies in accounting education in Iraqi universities as well as their failure to apply relevant standards. Among the most important findings of the study was that the international standards for accounting education are the principal foundation for guiding the development of accounting education curricula, the development of accounting graduate knowledge and skills, keeping up with developments in education standards.

A study by Elif et al (2012) on accounting education in Turkey addressed the expectations of accounting students. The study analyzed the extent to which the expectations of accounting students at Uludag University, one of Turkey's most prestigious universities, were satisfied by the university. The study concluded that accounting education could not be characterized as effective.

An exploratory study by AlMotairy, \& AlTurky (2012) sought to identify the accounting education curricula in Saudi universities, in light of the main requirements for the IFRS. The study concluded that the majority of the sample of academics from Saudi universities approve the adoption of standards for financial reporting. The study also emphasizes the need to teach IFRS.

Nassar et al.'s (2013) study investigates the significant decline in the education of graduates from Jordanian universities, and confirms that there are deficiencies in the knowledge that students acquired during their university education, including a lack of the skills needed to practice the accounting profession.

The researchers Mami, \& Mira (2013) focused on the importance and role of accounting curricula in improving and developing professional accounting practices. The researchers concluded that the skills and knowledge expected of education curricula taught to accounting graduates are appropriate for the required training and development of professional accountants. 
A study by Alzu'bi (2014) measures the ability of the educational process of accounting departments at Jordanian universities to graduate qualified accounting talent. The study found that the curricula were only capable of providing graduates with $67 \%$ of the required theoretical knowledge, due to study plans that were not appropriate to the current practical applications, and due to traditional teaching methods.

Al-Saqe (2014) studied the development of education programs at accounting departments to improve the capabilities and qualifications of graduates, in order to meet the needs of the job market. The study found that accounting education programs were deficient and thus produced accounting students who were not qualified for work required in the job market.

A recent study by Al-Khadash \& Alqawasami (2015), which they discussed at the annual conference of the Gulf Cooperation Council Accounting \& Auditing Organization in Bahrain, studied the extent to which the product of accounting education programs in Jordan meet the main requirements of the accounting profession, as required by the job market and stipulated in international standards for accounting education. The study found that many accounting curricula taught in universities were deficient in that they focused on memorization of knowledge rather than on learning, skills development and ethics, as well as deficient in contributing to the development of rigorous accounting practices among professional accountants. These deficiencies resulted in producing graduates who are incapable of practicing the accounting profession as required in the job market.

In summary, the literature underlined the importance of university role in modernizing study plans to achieve many goals such as, improving accounting education outcomes and narrowing the gap between university education and the employers' needs. It is also notable that there is a lack in studies about accounting education standards in Jordan, as well as a lack of studies about the importance of the unification of the study plans to reduce the variation in the level of knowledge of students who enroll to the university competency test. This study contributes to fill the gap in the existing literature by investigating the extent of Jordanian universities' compliance with the second international standard of accounting education and proposes a standardized study plan.

\section{Theoretical Framework of the Study}

The increasing international attention on the quality of education produced by educational systems, including accounting education, comes after repeated criticism of the decline in educational outcomes and the accompanying contemporary challenges resulting from technological developments, globalization, the communications revolution, and changes in international financial markets (Musa, \& Almakori,, 2007). Nassar et al.'s (2013) pointed out that increased attention on the accounting education is focused on developing knowledge for the accounting and auditing professions, where Boyer (1990) stressed that accounting education must balance various educational outcomes including making technical and theoretical progress, and covering knowledge or practical elements to meet the needs of both the learner and the accounting.

\subsection{International Standards for Accounting Education}

It is necessary to view accounting education as a comprehensive information system that incorporates a group of interacting elements, with the purpose of achieving the goals of educational organizations that work to produce qualified accounting talent (Sterling, 2001). The International Accounting Education Standards (IAES) are instructions and guidelines, first issued in 2003, that provide an educational framework for acquiring knowledge, developing skills, and acquiring practical experience. The first 6 standards were issued in 2003, followed by a seventh in 2004, and an eighth in 2006 , with all accounting committees confirming the importance of complying with these standards in order to attract the most qualified and effective accounting talent. (IES 1, Par. 5)

Due to continuous and persistent efforts, the International Accounting Education Standards Board (IAESB) amended the IAES in 2013 in order to continue developing the profession and to meet the needs of the job market (Alfateh, 2014). The revised standard number 1, "Entry Requirements to Professional Accounting Education Programs", effective as of the beginning of 2014, was issued to help protect public interests through the establishment of fair and appropriate admission requirements for accounting programs, thus also helping potential students to make appropriate career decisions (IES 1, 2015).

The importance of these standards lie in reducing international disagreement regarding the appropriate qualifications for accounting professionals, simplifying the procedures for international mobility and communications for accounting professionals, and helping reduce problems related to the compliance of educational institutes with the most important requirements in terms of their impact on the quality of education outcomes (IFAC, 2010; Alfateh, 2014). 


\subsection{International Education Standard - (IES 2) Technical Competence}

This study summarizes the content of professional accounting education programs of IAES (the issuance of 2005) and learning outcomes for technical competence of the recent version (issuance of 2015) (IES 2, 2014, para.3; IES 2, 2015, para.7). This summarization facilitates content analysis procedures and ensures the validity of the study plans for an appropriate period.

Based on that, the study focuses on the following technical competence \& primary knowledges derived from (IES 2):

a) Accounting, finance and related professional knowledge. This was further summarized into the following competence areas: financial accounting and reporting, management accounting, taxations, audit and assurance.

b) Organizational, economic and business professional knowledge. This was further summarized into the following competence areas: finance and financial management, governance, risk management and internal control, business laws and regulation, business and organization environment, economics, Business strategy, and management.

c) Information technology professional knowledge. This was further summarized into the following competence areas: general knowledge of IT, using accounting information \& control system to support decision making, accounting using computer applications.

6.3 The Role of Jordanian Universities in Developing the Technical Competence for Accounting Learning Outcomes Complying with IES 2

Jordanian universities are considered independent educational institutions in terms of their business and other activities, whether academic or financial. The primary supervisory and monitoring responsibility for these universities is carried out by the Jordanian Ministry of Higher Education and the Higher Education Accreditation Commission (HEAC). The primary goal of the HEAC is to establish a strategy for evaluating the education outcomes of academic programs in educational institutions (HEAC, 2015).

The educational process of accounting programs incorporate three primary concepts, including the organizational procedures for the education process, the teaching faculty of universities, and the nature of the study plans adopted by universities (Al-Khadash \& Alqawasami, 2015). Datta (1989) noted that the starting point for the route towards professional accounting qualification is to have technical educational methods that contribute to building continuously improving professional education outcomes, while continuing to organize its activities and resolve all the issues it faces.

There are a number of challenges facing the educational process of Jordanian universities for producing qualified accounting talent to support the needs of the job market. These challenges include a lack of standardized accounting education plans and curricula across Jordanian universities, differences in teaching languages used to deliver accounting education (i.e. Arabic and English), differences in the entry requirements to accounting education programs, a lack of qualified accounting education talent due to their migration to other countries in search of a better economic situation, and universities' lack of subspecialties in accounting education. In addition to these challenges, some universities, particularly public universities, are incapable of achieving or maintaining accreditation standards, or lack the facilities and infrastructure required for modern, technology assisted, teaching methods.

\section{Analysis and Discussion of Study Plans' Contents}

Through identifying the most important themes of accounting education standards of relevance to this study, it is possible to analyze the content of the education plans and curricula adopted by accounting departments of the universities in the sample, as follows:

7.1 Extent to Which Universities Comply with IES 2 in the Development of Education Plans and Curricula for Accounting, Finance and Related Professional Knowledge

Through studying the study plans for accounting programs for the sample universities, in order to determine the extent to which the universities comply with IES 2 in the development of education plans and curricula for accounting and finance knowledge, the following findings were developed:

Firstly, summary of units included/not included in the study plan for the sample universities, in regard to accounting, finance and related professional knowledge: 
Table 1. Units included/not included in the accounting programs for the sample universities in regard to accounting, finance and related professional knowledge

\begin{tabular}{|c|c|c|c|c|c|c|c|c|c|c|}
\hline \multirow[t]{2}{*}{$\begin{array}{l}\text { Units of accounting, finance and } \\
\text { related professional knowledge }\end{array}$} & \multicolumn{10}{|c|}{$\begin{array}{l}\text { Included/not included in the accounting programs for the sample } \\
\text { universities }\end{array}$} \\
\hline & 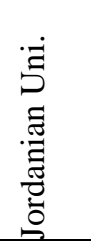 & 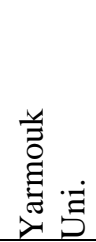 & 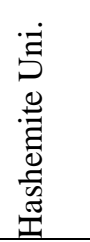 & 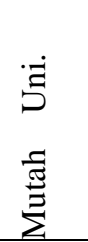 & 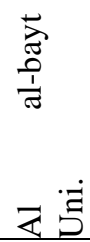 & 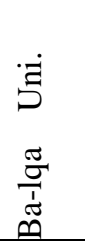 & 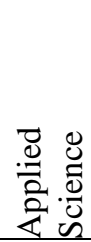 & 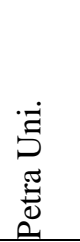 & 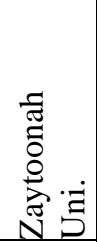 & 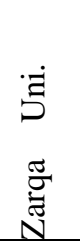 \\
\hline Principles \& financial reporting & Yes & Yes & Yes & Yes & Yes & Yes & Yes & Yes & Yes & Yes \\
\hline Intermediate accounting & Yes & Yes & Yes & Yes & Yes & Yes & Yes & Yes & Yes & Yes \\
\hline Corporate accounting & Yes & Yes & Yes & Yes & Yes & Yes & Yes & Yes & Yes & Yes \\
\hline Advanced financial accounting & Yes & Yes & Yes & Yes & Yes & Yes & Yes & Yes & Yes & Yes \\
\hline International accounting Standards & Yes & Yes & Yes & Yes & Yes & Yes & Yes & Yes & No & Yes \\
\hline Accounting theory & Yes & Yes & Yes & Yes & Yes & Yes & Yes & Yes & Yes & Yes \\
\hline International standards on auditing & No & No & No & Yes & No & Yes & No & Yes & No & Yes \\
\hline Managerial accounting \& control & Yes & Yes & Yes & Yes & Yes & Yes & Yes & Yes & Yes & Yes \\
\hline Cost accounting & Yes & Yes & Yes & Yes & Yes & Yes & Yes & Yes & Yes & Yes \\
\hline Taxation & Yes & Yes & Yes & Yes & Yes & Yes & Yes & Yes & Yes & Yes \\
\hline Auditing & Yes & Yes & Yes & Yes & Yes & Yes & Yes & Yes & Yes & Yes \\
\hline Financial statement analysis & Yes & Yes & Yes & Yes & Yes & Yes & Yes & Yes & Yes & Yes \\
\hline Profession ethics \& values & No & No & Yes & No & No & No & No & No & No & No \\
\hline Government accounting \& NGOs & Yes & Yes & Yes & Yes & Yes & Yes & Yes & Yes & Yes & Yes \\
\hline
\end{tabular}

Source: IES 2 and data gathered by the researchers from accounting programs of the sample universities.

The curricula and study plans of the sample universities' accounting programs in the area of accounting and financial professional knowledge show an $87 \%$ match with the subject requirements of IES 2 . However, there are a number of other observations regarding these plans and courses:

1. None of the universities in the sample offered the Accounting Profession Ethics course which is considered one of the most important topics stipulated in IES 2.

2. A large proportion of the universities in the sample did not offer the International Auditing Standards course required in IES 2, which is of particular importance given Jordan's adoption of these auditing standards.

3. Many of the courses do not include sufficient teaching units to cover the required topics, i.e. while course titles matched the requirements of IES 2, actual course content did not adequately cover the required details. This finding is based on interviews with groups of students from the sample universities, conducted at the end of the first academic term of 2015/2016.

4. Many of the study plans of the sample universities were not continuously and consistently updated as required by IES 2. Most such plans were not updated for over 4 to 5 years. This information was obtained through accessing the universities' websites and reviewing the latest changes and developments in the accounting study plans.

In summary, these findings show that a significant proportion of the accounting education curricula in the area of accounting and financial professional knowledge at the sample universities do not match the requirements of the IES 2. Therefore, we can conclude that Jordanian universities do not have a role in the trend towards the development of technical competence for accounting learning outcomes in the curricula for accounting and financial professional knowledge that complies with the second international standard for accounting education. 
7.2 Extent to which Universities Comply with IES 2 in the Development of Education Plans and Curricula for Organization, Financing, Business and Economics professional Knowledge

Through studying the study plans for accounting programs for the sample universities, in order to determine the extent to which the universities comply with IES 2 in the development of education plans and curricula for organization, financing, business and economics knowledge, the following findings were developed:

Secondly, summary of units included/not included in the study plan for the sample universities, in regard to Organizational and business knowledge:

Table 2. Units included/not included in the accounting programs for the sample universities in regard to organizational, business and economic professional knowledge

\begin{tabular}{|c|c|c|c|c|c|c|c|c|c|c|}
\hline \multirow[t]{2}{*}{$\begin{array}{l}\text { Units of Organizational and } \\
\text { business professional knowledge }\end{array}$} & \multicolumn{10}{|c|}{$\begin{array}{l}\text { Included/not included in the accounting programs for the sample } \\
\text { universities }\end{array}$} \\
\hline & 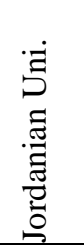 & 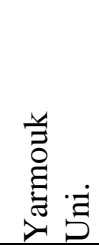 & 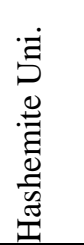 & 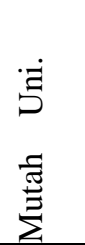 & $\begin{array}{l}\text { 胥 } \\
\frac{0}{1} \\
\frac{1}{\pi} \\
\text { \& }\end{array}$ & $\begin{array}{l}\dot{\vec{g}} \\
\dot{\tilde{\sigma}} \\
\frac{\tilde{\sigma}}{\tilde{D}}\end{array}$ & 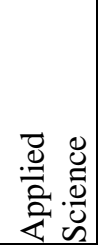 & 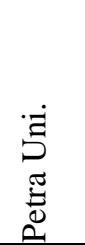 & 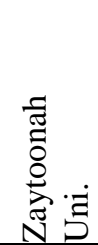 & 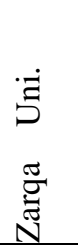 \\
\hline -Principles of microeconomic & Yes & No & Yes & Yes & Yes & Yes & Yes & Yes & Yes & Yes \\
\hline -Principles of macroeconomic & Yes & Yes & Yes & Yes & Yes & Yes & Yes & Yes & Yes & Yes \\
\hline -Principles of management & Yes & Yes & Yes & Yes & Yes & Yes & Yes & Yes & Yes & Yes \\
\hline -Principles of statistics & Yes & Yes & Yes & Yes & Yes & Yes & Yes & Yes & Yes & Yes \\
\hline $\begin{array}{l}\text {-Corporate governance \& risk } \\
\text { management }\end{array}$ & No & No & No & No & No & No & No & No & No & No \\
\hline -Business ethics & Yes & No & Yes & No & No & No & No & No & No & No \\
\hline -Financial markets & Yes & No & Yes & No & No & No & Yes & No & No & No \\
\hline -Financial management & Yes & Yes & Yes & Yes & Yes & No & Yes & Yes & Yes & Yes \\
\hline - Organizational behavior & Yes & Yes & No & Yes & No & No & No & No & No & No \\
\hline - Strategic management & No & No & No & Yes & No & No & Yes & No & No & Yes \\
\hline -Marketing & Yes & No & No & Yes & No & Yes & Yes & Yes & Yes & No \\
\hline -Business \& foreign trade & Yes & No & No & No & No & No & No & Yes & Yes & No \\
\hline $\begin{array}{l}\text {-E-commerce, globalization \& } \\
\text { multinational corporations }\end{array}$ & No & No & Yes & Yes & Yes & No & Yes & No & No & No \\
\hline Commercial law & No & No & Yes & No & No & Yes & No & Yes & Yes & Yes \\
\hline Financial instruments & Yes & NO & Yes & No & No & Yes & Yes & No & No & No \\
\hline
\end{tabular}

Source: IES 2 and data gathered by the researchers from accounting programs of the sample universities.

The curricula and study plans of the sample universities' accounting programs in the area of organizational and business professional knowledge show a $49 \%$ match with the subject requirements of IES 2 . There are a number of other observations regarding these plans and courses:

1. None of the universities in the sample offered the Corporate Governance and Risk Management course.

2. A large proportion of business environment related courses were not offered by the universities in the sample, including courses on organization behavior, project management, strategic management, marketing and business ethics.

3. A large proportion of universities in the sample did not offer courses related to External and Foreign Trade, which is interesting given the trend towards globalization and the spread of multinational businesses and the consequent accounting activities. 
4. A large proportion of universities in the sample did not offer the Commercial Law course, which covers a part of the topics regarding the financial legislation related to budgets, taxes and the Companies Law.

In summary, these findings show that a large proportion of the accounting education curricula in the area of organization, financing, business and economics knowledge at the sample universities do not match the requirements of the IES 2. Therefore, we conclude that Jordanian universities do not have a role in the trend towards the development of technical competence for accounting learning outcomes in the curricula for organization, financing, business and economics professional knowledge that complies with the second international standard for accounting education.

7.3 Extent to which Universities Comply with IES 2 in the Development of Education Plans and Curricula for Information Technology Knowledge

Through studying the study plans for accounting programs for the sample universities, in order to determine the extent to which the universities comply with IES 2 in the development of education plans and curricula for Information Technology knowledge, the following findings were developed:

Thirdly, summary of units included/not included in the study plan for the sample universities, in regard to Information Technology knowledge:

Table 3. Units included/not included in the accounting programs for the sample universities in regard to Information Technology professional knowledge

\begin{tabular}{|c|c|c|c|c|c|c|c|c|c|c|}
\hline \multirow[t]{2}{*}{$\begin{array}{l}\text { Units of Information Technology } \\
\text { professional knowledge }\end{array}$} & \multicolumn{10}{|c|}{$\begin{array}{l}\text { Included/not included in the accounting programs for the sample } \\
\text { universities }\end{array}$} \\
\hline & 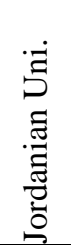 & 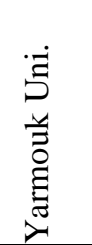 & 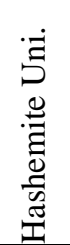 & 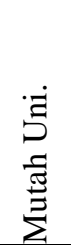 & 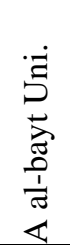 & 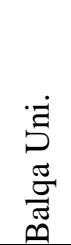 & 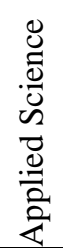 & 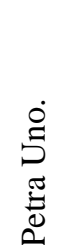 & 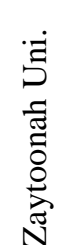 & 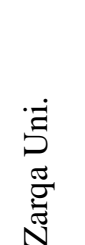 \\
\hline -General knowledge of IT & Yes & Yes & Yes & Yes & Yes & Yes & Yes & Yes & Yes & Yes \\
\hline $\begin{array}{l}\text {-Accounting information \& control } \\
\text { system }\end{array}$ & Yes & Yes & Yes & Yes & Yes & Yes & Yes & Yes & Yes & Yes \\
\hline $\begin{array}{l}\text {-Accounting using computer } \\
\text { applications }\end{array}$ & Yes & Yes & Yes & Yes & Yes & Yes & Yes & Yes & Yes & Yes \\
\hline
\end{tabular}

Source: IES 2 and data gathered by the researchers from accounting programs of the sample universities.

The curricula and study plans of the sample universities' accounting programs in the area of Information Technology professional knowledge show a $100 \%$ match with the subject requirements of IES 2 . There are, however, a number of other observations regarding these plans and courses:

1. The courses offered by the majority of universities in the sample do not include sufficient core topics to cover professional knowledge of IT, such as using IT for decision making. Those topics are essential as they provide students with a comprehensive knowledge of information technologies.

2. The majority of the accounting courses related to information technology deliver information in the form of theory and do not teach through practical application.

3. The majority of Jordanian universities do not have sufficient computing facilities that are appropriately prepared for accounting applications, contributing to a lack of information technology knowledge among students.

In summary, these findings show that a large proportion of the accounting education curricula in the area of Information Technology knowledge at the sample universities do not match the requirements of the IES 2 . Therefore, we conclude that Jordanian universities do not have a role in the trend towards the development of technical competence for accounting learning outcomes in the curricula for Information Technology professional knowledge that complies with the second international standard for accounting education. 


\section{Results and Recommendations}

\subsection{Results}

Analysis has shown that Jordanian universities do not satisfy the IES 2 requirements for imparting sufficient knowledge in topics related to accounting specialties. The following results confirm the findings of prior studies, including Al-Khadash \& Alqawasmi (2015), Nassar et al. (2013), Alzu'bi (2014) and Alnawaisa \& Alsaboo (2009):

1. A large proportion of the curricula in Jordanian universities' accounting departments related to professional competence of accounting and financial knowledge, organization, financing, business and economics knowledge, as well as Information Technology knowledge, do not meet the content requirements stipulated in IES 2, which represents a deficiency in professional accounting education programs.

2. All of the participants in the interview revealed that many of the courses offered do not include sufficient teaching topics to cover the required objectives of the courses, i.e. while course titles matched the requirements of IES 2, actual course content did not adequately cover the required details.

3. Many of the study plans of the sample universities were not continuously and consistently updated as revealed by the majority of the participants.

4. The disparities in the results of the university competency test among the Jordanian universities were attributed, by all of the study participants, to the poor accounting curricula on the one hand and to the non-unified curricula on the other hand.

\subsection{Recommendations}

1. Universities should work to standardize and unify accounting education curricula across all Jordanian universities.

2. Accounting education curricula in the areas of accounting and financial knowledge, organization, financing, business and economics knowledge, and Information Technology knowledge, should be designed to meet the requirements of the IES 2.

3. It is recommended that the model curricula suggested in the IES 2 should be accredited and adopted by Jordan's HEAC so that the curricula can be generally applied to all Jordanian universities.

4. Universities should require their accounting departments to annually revise their study plans to incorporate new topics as required by the IES 2 .

5. Universities should provide modern communication technologies appropriate to the transfer of technical knowledge.

In response to the results and recommendations of this study, the researchers have developed a suggested model for accounting study plan that complies with both accounting education standard \#2 and the requirements of Higher Education Accreditation Commission in Jordan. The proposed Study plan is presented in the next section.

\section{The Proposed Accounting Study Plan (132) Credit Hours}

First: University Requirements (Compulsory \& Elective) 27 Credit Hours

Second: Faculty Compulsory Requirements: 27 Credit Hours

\begin{tabular}{|l|l|}
\hline Course Title & Credit Hours \\
\hline Principles of Accounting 1 & 3 \\
\hline Principles of Accounting 2 & 3 \\
\hline Principles of Management & 3 \\
\hline Principles Of Microeconomic & 3 \\
\hline Principles of Statistics & 3 \\
\hline Scientific Research Methods & 3 \\
\hline Profession \& Business ethics & 3 \\
\hline Financial Management \& Analysis & 3 \\
\hline Mathematics for Business & 3 \\
\hline Total & $\mathbf{2 7}$ \\
\hline
\end{tabular}


Third: Specialization Compulsory Requirements (66) Credit Hours

\begin{tabular}{|c|c|}
\hline Course Title & Credit Hours \\
\hline Intermediate Accounting 1 & 3 \\
\hline Intermediate Accounting 2 & 3 \\
\hline Corporate Accounting & 3 \\
\hline Cost Accounting & 3 \\
\hline Managerial Accounting \& Decision Making & 3 \\
\hline Government \& NGOs Accounting & 3 \\
\hline Banks and Insurance Accounting & 3 \\
\hline Tax Accounting: income \& sales tax & 3 \\
\hline Auditing & 3 \\
\hline Accounting Computer Application & 3 \\
\hline Accounting Theory & 3 \\
\hline Accounting Information System & 3 \\
\hline International Auditing Standards & 3 \\
\hline Advanced Accounting & 3 \\
\hline Organizational Behavior & 3 \\
\hline International Accounting Standard 1 & 3 \\
\hline Corporate governance - Accounting Emphasis & 3 \\
\hline Investment Management & 3 \\
\hline International Business and Globalization & 3 \\
\hline Strategic Management & 3 \\
\hline Graduation Project & 3 \\
\hline $\begin{array}{l}\text { Fieldwork Training for Accounting- } 140 \text { actual training hours } \\
\text { per semester }\end{array}$ & 3 \\
\hline Total & 66 \\
\hline
\end{tabular}

Fourth: Specialization Elective Requirement (12) Credit Hours

\begin{tabular}{|l|l|l|}
\hline \multirow{4}{*}{ Group A } & Course Title & $\begin{array}{l}\text { Credit } \\
\text { Hours }\end{array}$ \\
\hline \multirow{4}{*}{\begin{tabular}{l} 
Hours Credit \\
\cline { 2 - 3 }
\end{tabular}} & Principles of Islamic Banking \& Accounting & 3 \\
\cline { 2 - 3 } & Computerized Accounting & 3 \\
\cline { 2 - 3 } & Advanced Financial Statement Analysis & 3 \\
\cline { 2 - 3 } & Contemporary Problems in Accounting & 3 \\
\cline { 2 - 3 } & IT Auditing \& Data Security & 3 \\
\cline { 2 - 3 } & International Accounting & 3 \\
\cline { 2 - 3 } & International Accounting Standard 2 & 3 \\
\cline { 2 - 3 } & Hospital, Hotel \& Tourism Accounting & 3 \\
\hline
\end{tabular}




\begin{tabular}{||l|l|l|}
\hline \multirow{5}{*}{} & Management Information System & 3 \\
\cline { 2 - 3 } & Risk Management \& International Conflicts & 3 \\
\cline { 2 - 3 } & Computerized Statistical Analysis & 3 \\
\cline { 2 - 3 } Group B & E-commerce & 3 \\
\cline { 2 - 3 } Hours Credit & Knowledge Management & 3 \\
\cline { 2 - 3 } & Production \& Operations Management & 3 \\
\cline { 2 - 3 } & Commercial Law & 3 \\
\cline { 2 - 3 } & Financial Instruments and Markets & 3 \\
\cline { 2 - 3 } & Project Management & 3 \\
\cline { 2 - 3 } & Marketing & 3 \\
\cline { 2 - 3 } & Human Resource Management & 3 \\
\cline { 2 - 3 } & Operations Research & 3 \\
\hline
\end{tabular}

\section{References}

Al- brecht W. S., Sack R. J. (2010). Accounting Education: Charting the Courses through a Perilous Future", Accounting Education Series, 16. https://www2.aaahq.org/pubs/AESv16/toc.htm

Alfateh, A. A. (2014). Proposed Conception of Application of Standards Accounting Education and its Role in Quality Control of Accounting Curricula in Saudi Universities. Arab Journal for quality assurance in higher education, 7(16), 109-138.

Al-Jalili, M., \& Dhanoon, A. (2010). The use of international education standards for the professional accountants in the development of accounting curriculum for the bachelor degree in Iraq. Rafidain Development Journal, 32(99), 1-33.

Al-Khadash, H. \& Alqawasmi, H. (2015). The compatibility between the accounting education outcomes and the requirements of professional practice according to market needs and IES, Working paper presented at the annual forum for GCC Accounting and Audit organization, held in Bahrain- Manama in May, 2015.

AlMotairy, O., \& AlTurky, K. (2012). Survey of the Accounting Curriculum and IFRS in Saudi Universities: Academic Perspective, Journal of Economics and Administration, Qassim University, 5(2), 98-131.

Alnawaisa M., \& Alsbou, M. (2009). Accounting curriculum and its impact on building professional knowledge and skills - an analytical study from the perspective of students expected to graduate in Accounting / Applied Science University. Culture and Development Association - a member of the Academy of Scientific Research and Technology - Cairo, Issue 31.

AlSaqe, M. (2014). The development of accounting education programs and raising the efficiency of educational output to meet the requirements of the market: from the perspective of students and faculty members of the accounting departments, Working paper presented for "Integration education outputs with labor market in the public and private sector conference" held in Amman-Jordan during 28-April to 1-May 2014.

Attia, K. \& Al-Zahrani, A. (2008). Proposed model for assessing the accounting programs quality from the perspective of academic accreditation. the Arab Journal for Quality Assurance in Higher Education, 1(2), $13-62$.

AlZu'bi, A. M. (2014). The Ability of Accounting Departments at Jordanian universities for Graduating Qualified Graduates: Graduates Perspectives. Arab Journal for quality assurance in higher education, 7(18), 59-80.

Boyer, E. L. (1990). Scholarship Reconsidered: Priorities of the professoriate, Carnegie Foundation for the advancement of science, Princeton. N. J, P. 74. Available at: https://www.csusm.edu/community/facultyengagement/scholarshipreconsidered.pdf

Chen, J., Damtew D., Banatte, J.M., \& Mapp J. (2010). Information technology competence expected in undergraduate accounting graduates. Research in Higher Education Journal, 3, 1 - 7.

Datta, K. G. (1989). The role of accounting Education and Research in Industrial Development”, A paper presented at (SICAE). Tokyo, 30-51. 
Elif Y., Mehlike S., \& Adem C. (2012). Accounting Education in Turkey and Professional Accountant Candidates Expectations from Accounting Education: Uludage, University Application. Business and Economic Research Journal, 3, 91-108.

Gammie, E., \& Joyceb, Y. (2009). Competence-based Approaches to the Assessment of Professional Accountancy Training Work Experience Requirements: The ICAS Experience. Accounting Education, 18(4-5), 443-466. http://dx.doi.org/10.1080/09639280902719465

HEAC. (2015). The Higher Education Accreditation Commission (HEAC) in Jordan. The universities competency test in Jordanian. See (http://www.heac.org.jo/?page_id=613)

Mami, T. A., \& Mira, A. F. (2013). The role of the accounting curriculum in the development of the practice of the accounting profession: Working paper presented as applied study of University of Zawia, for the conference of the reality of the accounting profession, Libya, Tripoli, during the period 27-28 / 2/2013.

Mohammad, F. (2016). The Compatibility between Accounting Education in Sudanese Universities with The Requirements of Contemporary Business Environment and The International Federation of Accountants from The Perspective of Employers and Teaching Staff. Arab Journal for quality assurance in higher education, 9(23), 191-213. https://www.ust.edu/uaqe/count/2016/1/9.pdf

Musa, A. \& Almakori, N. (2007). The Reality of accounting education, and its impact on the professionalization of university graduates, working paper presented at the 2nd scientific conference on accounting education in Libya - realistic and the possibilities of development, the Academy of Graduate Studies, Tripoli 26-27/5/ 2007.

Nassar, M., Al- Kadash, H., Mahd, O. (2013). Accounting Education and Accountancy profession in Jordan: The current status and the processes of improvement. Research Journal of Finance and Accounting, 4(11), 107-119.

Nishat Abbasi. (2013). Competency Approach to Accounting Education: A Global View, Journal of Finance and Accountancy, (13), 1-19. Available at: http://www.aabri.com/manuscripts/131566.pdf

Sterling, R. R. (2001). Accounting Research, Education and Practice. Journal of Accountancy, 52(6).

Weiss, J. M. (2011). Implementing (IFRS) Curriculum Into Accounting Programs. The CPA Journal, (April), 62-63. http://maaw.info/TheCPAJournal-4.htm

IES 2. (2014). International Education Standard No. 2. The International Accounting Education Standards Board (IAESB). Accessed on October 2015, from http://www.ifac.org/publications-resources/2014-handbook-international-education-pronouncements

IES 2. (2015). International Education Standard No. 2. The International Accounting Education Standards Board (IAESB). Accessed $\quad$ on $\quad$ October 2015, from http://www.ifac.org/publications-resources/2015-handbook-international-education-pronouncements

\section{Notes}

Note 1. The competency test of the Jordanian universities is a national test administered by The Higher Education Accreditation Commission (HEAC) in Jordan. The test is conducted by the end of each semester and applicable to all Jordanian universities, with main aim to test the quality of the universities outcomes for each discipline. See (http://www.heac.org.jo/?page_id=613) 